\title{
Richness of Chrysomelidae (Coleoptera) depends on the area and habitat structure in semideciduous forest remnants
}

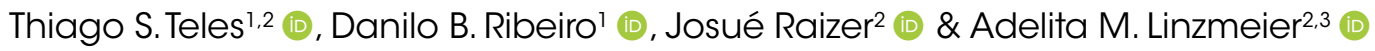

\begin{abstract}
1. Universidade Federal de Mato Grosso do Sul, Instituto de Biociências, Programa de Pós-Graduação em Ecologia e Conservação, 79070-900 Campo Grande, MS, Brasil. (tsteles@gmail.com; biodbr@gmail.com)

2. Universidade Federal da Grande Dourados, Faculdade de Ciências Biológicas e Ambientais, Programa de Pós-Graduação em Entomologia e Conservação da Biodiversidade, 79804-970 Dourados, MS, Brasil. (jraizer@gmail.com)

3. Universidade Federal da Fronteira Sul, Campus Realeza, 85770-000 Realeza, PR, Brasil. (alinzmeier@yahoo.com.br)
\end{abstract}

Received 12 August 2019

Accepted 9 October 2019

Published 2 December 2019

DOI 10.1590/1678-4766e2019040

\begin{abstract}
The total area of a habitat patch can increase the local species richness both directly (through balance between immigration and extinction) and indirectly (by increasing the habitat heterogeneity and/or as an effect of sample effort). More heterogeneous environments present a wider variety of resources and conditions, allowing species to coexist through niche differentiation. This study shows that the diversity of Chrysomelidae depends on the area and habitat structure of semideciduous forest remnants. We sampled 16 remnants with Malaise traps in August 2012 to March 2013. In order to characterize the habitat, the area, structural heterogeneity of the understory, coverage and canopy height were measured. These variables were used in a path analysis to determine their direct and indirect effects on leaf beetle diversity. A total of 450 specimens from 99 species and five subfamilies were captured. The total area and the understory heterogeneity presented a positive effect on species richness, while canopy cover exerted a negative one. The canopy height only had a negative and indirect effect on leaf beetle richness. In such fragments with more area and more open spaces, plant abundance and richness tend to be higher and favor the coexistence of many Chrysomelidae species.
\end{abstract}

KEYWORDS. Canopy, leaf beetle, Phytophaga, understory.

RESUMO. Riqueza de Chrysomelidae (Coleoptera) depende da área e da estrutura do habitat em remanescentes de floresta semidecídua. A área de uma mancha de habitat pode aumentar a riqueza local de espécies tanto diretamente (pelo balanço entre imigração e extinção) quanto indiretamente (por aumentar a heterogeneidade do habitat e/ou como efeito do esforço amostral). Ambientes mais heterogêneos apresentam maior variedade de recursos e condições permitindo a coexistência de espécies por diferenciação de nicho. Neste estudo mostramos que a riqueza de Chrysomelidae depende da área e da estrutura do habitat em remanescentes de floresta semidecidual. Realizamos amostragens com armadilhas Malaise em 16 remanescentes florestais entre agosto de 2012 e março de 2013. Para caracterizar o habitat, medimos a área, a heterogeneidade estrutural do sub-bosque, a cobertura e a altura do dossel. Estas variáveis foram utilizadas em uma análise de caminhos para determinar seus efeitos diretos e indiretos na riqueza de crisomelídeos. Capturamos 450 espécimes de 99 espécies e cinco subfamílias. A área total e a heterogeneidade do sub-bosque apresentaram um efeito positivo sobre a riqueza de espécies, enquanto a cobertura do dossel exerceu efeito direto negativo. A altura do dossel apresentou apenas efeito indireto e negativo sobre a riqueza de crisomelídeos. Em fragmentos com maior área e mais espaços abertos, provavelmente a abundância e a riqueza de plantas tendem a serem maiores, favorecendo a coexistência de muitas espécies de Chrysomelidae.

PALAVRAS-CHAVE. Dossel, besouros crisomelídeos, Phytophaga, sub-bosque.

Several factors influence the diversity and structure of insect communities, among which, habitat area size and habitat heterogeneity are major factors (SCHOWALTER, 2006). The species area relationship (SAR), considered one of the most robust empirical generalizations in ecology (RosENZWEIG, 1995), predicts that larger habitat patches hold more species than smaller ones, which can be explained by both direct and indirect effects. The direct effects may be related to the area per se with species richness as a function of the equilibrium of immigration and extinction (MACARTHUR \& WILSON, 1963). On the other hand, indirect effects may be related either to sample effect [larger areas require greater sample effort, thus more species are found (RosenzweIG, 1995)] or due to habitat heterogeneity [habitat heterogeneity increases as habitat area increases, allowing more species to coexist (MACARTHUR \& MACARTHUR, 1961; RoSENZWEIG, 1995)]. Besides such factors, in landscapes that have suffered from habitat loss and the fragmentation process, habitat size could exert an important role by acting directly and indirectly on the dynamics of inhabiting species. Smaller forest fragments tend to suffer more from edge effects than large ones. These effects include wind action that can increase tree fall and tree mortality, altering the forest structure and composition (LAURANCE, 1991).

Habitat heterogeneity involves measuring environmental variables such as habitat architecture or plant species composition that integrate the community (BEALS, 2006) because these effects are complex, elucidating 
these relationships has proven difficult. Multiple aspects of vegetation architecture or plant species composition, for example, may simultaneously affect animal communities and their constituent species. This hypothesis, initially developed by MacArthur \& MACARTHUR (1961), states that more heterogeneous environments present a greater variety of resources and conditions, allowing species to coexist through niche differentiation. Although the positive relationship between diversity and habitat heterogeneity has been demonstrated for many insect groups, some groups respond negatively to habitat heterogeneity (e.g., SILVA et al., 2010).

In forest environments, the canopy (both height and cover) is an important factor that determines heterogeneity, since it directly affects forest dynamics by interfering with the amount of available light, the provision of essential chemical nutrients (ANDERSON et al., 1969; SHAw \& Bible, 1996; Prescott, 2002), the coverage of shrubs and herbaceous plants, and species composition in the understory (Anderson et al., 1969; Chávez \& MacDonald, 2010). Thus, the canopy can be considered a very important physical structure for forests and forest remnants, as it determines the dynamics of the understory. Finally, the canopy directly and indirectly affects animal communities that forage in the understory. In addition, it can directly affect the diversity of heliophilous animals who prefer more illuminated areas for mating, oviposition and feeding (e.g., Grundel, Pavlovic \& Sulzman, 1998, who examined how the butterfly's behavior varied with canopy cover).

Chrysomelidae is one of the largest families of Coleoptera with about 36,000 species described worldwide (BOUCHARD et al., 2017) and is estimated to include over 60,000 (JoLIVET, 2015). These small beetles, which are mainly herbivores and commonly found in the herbaceous and shrub layer, are closely associated with their host plants (JOLIVET, 1988) and respond to changes in environmental quality (SMith \& WhitTAKer, 1980; LinzMEIER et al., 2006), as well as habitat heterogeneity (OHSAWA \& NAGAIKe, 2006).

Herein, the Chrysomelidae assemblage in forest remnants is described in relation to habitat area and structural factors. We hypothesized that the leaf beetle richness in remnant forest patches depends on the direct and indirect effects of habitat area, canopy structure (cover and height) and understory heterogeneity. As previous studies have shown (OhsaWa \& Nagaike, 2006; OhsaWa \& Shimokawa, 2011), these structures are important for leaf beetle dynamics in other forest types, thus these structures could be contributing to the variation in species richness in our study area.

\section{MATERIALS AND METHODS}

From August 2012 to March 2013, 60 samplings of Chrysomelidae were performed using Malaise traps inside 16 forest fragments in Dourados, Mato Grosso do Sul, Brazil (Fig. 1). These forest fragments are remnants of semi-deciduous alluvial forest (Atlantic Forest) and Cerrado, distributed within a landscape dominated by agriculture and planted pasture.

We placed 10 Malaise traps in the field at same time. Each trap was installed at least $30 \mathrm{~m}$ from the forest edge, towards the remnant center. For each collection, traps were exposed in the field for 14 days. Afterwards, 10 traps were installed in another location within the same or in another fragment. After the trap exposure period, insects were collected and prepared for identification and vouchers specimens were stored at the "Museu da Biodiversidade da Faculdade de Ciências Biológicas e Ambientais" (Universidade Federal da Grande Dourados). The leaf beetles were first separated into morphospecies and identified through comparisons with specimens deposited at the "Coleção Entomológica Pe. Jesus Santiago Moure" (Universidade Federal do Paraná).

The Chrysomelidae assemblage was characterized regarding the number of individuals (abundance) and species (richness) collected using the 60 samples. The abundance was calculated using the total number of individuals per species from each collection and area. After, we categorized abundances into classes according to Colwell (2013): 1) singletons (only one specimen), 2) doubletons (two specimens), 3) rare (three to ten specimens), 4) common (eleven to thirty specimens) and 5) very common (over thirty specimens). Regarding the species richness, we used the number of morphospecies (here after referred to as species) collected from each collection and each forest remnant. To determine the representativeness of our sample, we performed sample-based rarefaction/extrapolation and sample-completeness curves using the sample-size methodology (CHAO \& JosT, 2012) using the iNEXT package (Hshie et al., 2019) in R language (R Core Team, 2019). The extrapolation was calculated by doubling the abundance found in our survey. To estimate the total number of species in the assemblage, we used the non-parametric estimator Jackknife of first order.

Fragment areas were measured in the ArcGis (v. 10.5) through Landsat 8 images via the USGS EarthExplorer database (http://earthexplorer.usgs.gov/). Three environmental variables were measured to characterize the habitat: structural heterogeneity of the understory (here after referred to as understory heterogeneity), canopy cover, and canopy height. These variables were measured at $10 \mathrm{~m}$ perpendicular to the four sides of the traps. Then, each of the variables was averaged to characterize each collection site.

To measure the understory heterogeneity, we used a two-meter-high rod that was divided into four height classes $(0-50 \mathrm{~cm}, 51-100 \mathrm{~cm}, 101-150 \mathrm{~cm}$ and $151-200 \mathrm{~cm})$. This rod was positioned vertically and the number of times the vegetation reached each height class was counted. The heterogeneity value for each location was the inverse of the Shannon diversity index for height classes. The observer used the same rod to estimate the canopy height. To calculate canopy cover, a transparent plate marked with a $10 \mathrm{~cm} \mathrm{x}$ $10 \mathrm{~cm}$ square, which was divided into 100 squares of 1 $\mathrm{cm}^{2}$, was used. The observer reached out and positioned the plate vertically towards the canopy, looked through 


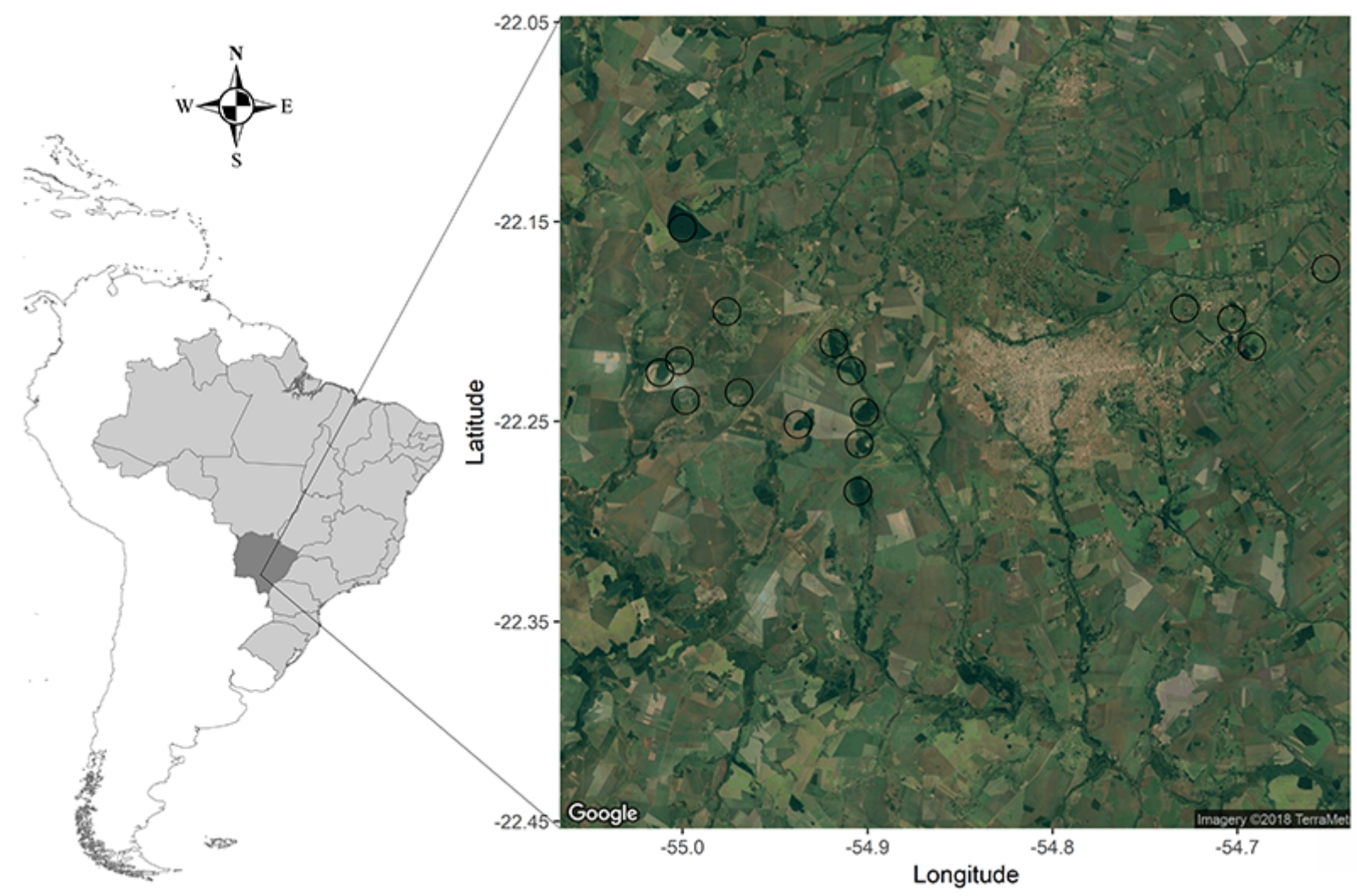

Fig. 1. Brazil (light grey), Mato Grosso do Sul State (dark grey) and the regions where the Chrysomelidae assemblage was collected (circles).

it, and counted the number of squares with $50 \%$ or more filled with canopy cover, which represented the coverage proportion. The environmental variables were standardized to remove differences between the variables' scales (mean zero and unit variance) (LEGENDRE \& LEGENDRE, 2012). For the relationship between Chrysomelidae assemblage and structural habitat characteristics, the first 60 samples were randomly rearranged in 15 samples without repetition, each consisting of four collections, considering the average values of environmental variables and total number of species in the statistical analysis.

To assess the direct and independent effects of each variable (area, canopy cover, canopy height and understory heterogeneity) on the richness of Chrysomelidae, data was run through a path analysis using the lavaan package (Rosseel, 2012) in R (R Core TeAm, 2019). This analysis is a straightforward extension of multiple regression that evaluates the relationship between a dependent variable and a set of independent variables and their own relationship. The difference between the multiple regression and path analysis is that the first assumes that both independent variables directly affect the dependent variable, while in the path analysis the analytical model is built according to a specific set of relationships between variables (SCHEINER et al., 2000). The strength of the relationship is obtained by the path coefficient, which is the standardized slopes of the regression of the dependent variable on the independent variable in the context of the other independent variable (SCHEINER et al., 2000). We considered the following relationships to construct our path diagram: the direct effects of area, canopy cover, canopy height and understory heterogeneity on Chrysomelidae species richness; the indirect effect of area on species richness via canopy cover, canopy height and understory heterogeneity; the indirect effects of canopy cover and canopy height on species richness via understory heterogeneity.

\section{RESULTS}

Four-hundred fifty Chrysomelidae individuals were collected, encompassing 99 species and five subfamilies (Tab. I). Galerucinae was the most abundant with 273 specimens $(60.67 \%$ of total) and had the highest richness with 43 species ( $43.43 \%$ of total), followed by Eumolpinae (124 individuals, 29 species), Cassidinae (29 individuals, 15 species), Cryptocephalinae (21 individuals, nine species) and Bruchinae (three individuals, three species). Fifty-one singletons were captured from the described species (51.5\%), 16 doubletons (16.2\%), 22 rare (22.2\%), 5 common (5.05\%), and 5 very common $(5.05 \%)$.

A species of Wanderbiltiana Bechyné, 1955 was the most frequent in both the traps and forest remnants, present in 19 of the 60 samples (32\% of fragments) and $W$. sejuncta (Harold, 1880) in 18 samples (30\% of fragments). These two species occurred in nine of the 16 forest remnants $(56 \%$ of fragments) and represented $16 \%$ of the total abundance.

The abundance-based rarefaction/extrapolation curve indicates that the 99 species found only represent a portion 
of the Chrysomelidae community and even when doubling the abundance of individuals, the asymptote was not reached (Fig. 2a). The estimated sample coverage curve shows that the richness of the Chrysomelidae assemblage was well represented with a sample coverage percentage around $88 \%$ (Fig. 2b). This result indicates that about $88 \%$ of the individuals in the assemblage belong to the 99 species found. According to the non-parametric estimator Jackknife 1, the community is composed of $158( \pm 14)$ species, indicating that about $63 \%$ of the species richness was sampled.

Fragment areas ranged from 0.61 ha to 308 ha $(82.77 \pm$ 105.82 ). The canopy cover ranged from $82 \%$ to $99 \%$ (mean of $90.4 \% \pm$ standard error $=5.8$ ), height ranged from $7.56 \mathrm{~m}$ to $12.87 \mathrm{~m}(10.13 \pm 1.5)$ and heterogeneity of the understory from -1.33 to $-0.89(-1.17 \pm 0.1)$. Leaf beetle richness had a minimum of six species and maximum of $21(12 \pm 5)$ in 15 samples consisting of four collections each, which were taken (without replacement) from the total set of 60 collections.

The path analysis showed significantly positive direct effects of area and understory heterogeneity and a significantly negative direct effect of canopy cover on Chrysomelidae species richness (Fig. 3). Considering the indirect effects of the variables on species richness, only canopy height showed a negative and significant effect via understory heterogeneity (path coefficient $=-0.522 * 2.285=$ -1.192 ). The remaining indirect effects were not significant.

\section{DISCUSSION}

The Chrysomelidae assemblage from forest remnants in Dourados, Mato Grosso do Sul is similar to other insect communities previously studied (FLOWERS \& HANSON, 2003; LINZMEIER et al., 2006; LINZMEIER \& RIBEIRO-COSTA, 2012), regarding both the abundance and richness of species. In this study, Malaise traps were periodically relocated (14 days of exposure at each location), which differs from other studies where traps remained in the same location throughout the entire study period (e.g. LINZMEIER et al., 2006; AsLAN \& Ayvaz, 2009; LinzMEIER \& Ribeiro-CostA, 2012, 2013). Only five of the nine subfamilies that occur in Brazil (CASARI \& IDE, 2012) were found in this study. Galerucinae was the subfamily that presented the highest richness in our study, reflecting its large number of species distributed worldwide (RILEY et al., 2002).

The absence of asymptotic curves in the rarefaction cumulative species analyses was expected since our system is very diverse. This result could reflect the greater differences observed between species composition in different fragments (Teles et al., data not published), indicating that in the entire study region there are habitat conditions that support distinctive species assemblages (GOTELLI \& COLWELL, 2011). In the highly diverse communities with many rare species, like tropical arthropods, sample richness may never stabilize

Tab. I. List of Chrysomelidae - species and morphospecies - sampled with Malaise traps in 16 remnants of semi-deciduous forest in Dourados, state of Mato Grosso do Sul, Brazil (Sites, number of remnants forests that species were sampled; Freq, frequence that species were sampled).

\begin{tabular}{|c|c|c|c|}
\hline Taxa & Sites & Freq & Abundance \\
\hline \multicolumn{4}{|l|}{ Galerucinae } \\
\hline Acanthonycha adusta (Bechyné, 1959) & 2 & 2 & 4 \\
\hline Acanthonycha sp. & 2 & 2 & 3 \\
\hline Asphaera sp. & 1 & 2 & 2 \\
\hline Brasilaphtona sp. 1 & 2 & 2 & 3 \\
\hline Brasilaphtona sp. 2 & 1 & 1 & 4 \\
\hline Diphaulaca viridipennis Clark, 1865 & 1 & 2 & 2 \\
\hline Heikertingerella sp. 1 & 1 & 1 & 1 \\
\hline Heikertingerella sp. 2 & 2 & 2 & 3 \\
\hline Hypolampsis sp. 1 & 3 & 3 & 4 \\
\hline Paracacoscelis sp. & 1 & 1 & 1 \\
\hline Systena sp. 1 & 5 & 9 & 32 \\
\hline Systena sp. 2 & 2 & 2 & 2 \\
\hline Systena sp. 3 & 1 & 1 & 1 \\
\hline Systena sp. 4 & 1 & 1 & 1 \\
\hline Trichaltica micros Bechyné, 1954 & 2 & 3 & 8 \\
\hline Wanderbiltiana sejuncta (Harold, 1880) & 9 & 17 & 36 \\
\hline Wanderbiltiana sp. & 9 & 19 & 35 \\
\hline Galerucinae sp. 1 & 4 & 4 & 53 \\
\hline Galerucinae sp. 2 & 2 & 4 & 14 \\
\hline Galerucinae sp. 3 & 3 & 3 & 3 \\
\hline Galerucinae sp. 4 & 3 & 4 & 32 \\
\hline Galerucinae sp. 5 & 1 & 1 & 1 \\
\hline Galerucinae sp. 6 & 1 & 1 & 1 \\
\hline Galerucinae sp. 7 & 1 & 1 & 1 \\
\hline Galerucinae sp. 8 & 1 & 1 & 1 \\
\hline Galerucinae sp. 9 & 1 & 1 & 1 \\
\hline Galerucinae sp. 10 & 1 & 1 & 2 \\
\hline Galerucinae sp. 11 & 2 & 2 & 2 \\
\hline Galerucinae sp. 12 & 1 & 1 & 1 \\
\hline Galerucinae sp. 13 & 1 & 1 & 1 \\
\hline Galerucinae sp. 14 & 1 & 1 & 1 \\
\hline
\end{tabular}


Tab. I. Cont.

\begin{tabular}{|c|c|c|c|}
\hline Taxa & Sites & Freq & Abundance \\
\hline Galerucinae sp. 15 & 1 & 1 & 1 \\
\hline Galerucinae sp. 16 & 1 & 1 & 1 \\
\hline Galerucinae sp. 17 & 1 & 1 & 1 \\
\hline Galerucinae sp. 18 & 1 & 1 & 1 \\
\hline Galerucinae sp. 19 & 1 & 1 & 1 \\
\hline Galerucinae sp. 20 & 1 & 1 & 1 \\
\hline Galerucinae sp. 21 & 1 & 1 & 1 \\
\hline Galerucinae sp. 22 & 2 & 2 & 3 \\
\hline Galerucinae sp. 23 & 2 & 2 & 2 \\
\hline Galerucinae sp. 24 & 2 & 1 & 2 \\
\hline Galerucinae sp. 25 & 1 & 2 & 2 \\
\hline Galerucinae sp. 26 & 1 & 1 & 1 \\
\hline \multicolumn{4}{|l|}{ Bruchinae } \\
\hline Caryobruchus sp. & 1 & 1 & 1 \\
\hline Meibomeus sp. & 1 & 1 & 1 \\
\hline Acanthoscelidini sp. & 1 & 1 & 1 \\
\hline \multicolumn{4}{|l|}{ Cassidinae } \\
\hline Charidotella (Metrionaspis) rubincuda (Guerin, 1844) & 1 & 1 & 1 \\
\hline Charidotis auroguttata (Boheman, 1855) & 1 & 1 & 1 \\
\hline Charidotis furunculus (Boheman, 1855) & 1 & 1 & 1 \\
\hline Charidotis sp. 1 & 1 & 1 & 2 \\
\hline Charidotis sp. 2 & 1 & 1 & 1 \\
\hline Hybosa sp. 1 & 4 & 6 & 7 \\
\hline Hybosa sp. 2 & 1 & 1 & 1 \\
\hline Ischnochodia annulus (Fabricius, 1781) & 3 & 3 & 3 \\
\hline Cassidinae sp. 1 & 1 & 1 & 2 \\
\hline Chalipus sp. 1 & 3 & 4 & 4 \\
\hline Octhispa sp. 1 & 2 & 2 & 2 \\
\hline Octhispa sp. 2 & 1 & 1 & 1 \\
\hline Hispini sp. 1 & 2 & 1 & 1 \\
\hline Hispini sp. 2 & 1 & 1 & 1 \\
\hline Hispini sp. 3 & 1 & 1 & 1 \\
\hline \multicolumn{4}{|l|}{ Cryptocephalinae } \\
\hline Urodera $\mathrm{sp}$ & 1 & 1 & 1 \\
\hline Cryptocephalinae sp. 1 & 2 & 2 & 3 \\
\hline Cryptocephalinae sp. 2 & 1 & 1 & 1 \\
\hline Cryptocephalinae sp. 3 & 1 & 1 & 1 \\
\hline Cryptocephalinae sp. 4 & 1 & 1 & 1 \\
\hline Cryptocephalinae sp. 5 & 1 & 1 & 1 \\
\hline Cryptocephalinae sp. 6 & 2 & 2 & 9 \\
\hline Cryptocephalinae sp. 7 & 1 & 1 & 2 \\
\hline Cryptocephalinae sp. 8 & 2 & 2 & 2 \\
\hline \multicolumn{4}{|l|}{ Eumolpinae } \\
\hline Colaspoides sp. & 1 & 2 & 3 \\
\hline Costalimaita ferruginea (Fabricius, 1801) & 3 & 3 & 24 \\
\hline Endocephalus bigatus Germar, 1824 & 2 & 3 & 4 \\
\hline Endocephalus sp. 1 & 1 & 2 & 11 \\
\hline Endocephalus sp. 2 & 1 & 1 & 1 \\
\hline Colaspis laeta (Germar, 1821) & 1 & 1 & 1 \\
\hline Colaspis sp. 1 & 5 & 7 & 15 \\
\hline Colaspis sp. 2 & 1 & 1 & 1 \\
\hline Colaspis sp. 3 & 3 & 3 & 3 \\
\hline Colaspis sp. 4 & 1 & 1 & 1 \\
\hline Colaspis sp. 5 & 1 & 1 & 1 \\
\hline Megascelidini sp. 1 & 1 & 1 & 5 \\
\hline Neoiphimeis sp. 1 & 1 & 1 & 4 \\
\hline Eumolpinae sp. 1 & 1 & 1 & 1 \\
\hline Eumolpinae sp. 2 & 2 & 2 & 2 \\
\hline Eumolpinae sp. 3 & 3 & 3 & 3 \\
\hline Eumolpinae sp. 4 & 4 & 4 & 9 \\
\hline Eumolpinae sp. 5 & 1 & 1 & 2 \\
\hline Eumolpinae sp. 6 & 1 & 2 & 2 \\
\hline Eumolpinae sp. 7 & 1 & 1 & 1 \\
\hline Eumolpinae sp. 8 & 1 & 1 & 1 \\
\hline Eumolpinae sp. 9 & 1 & 1 & 1 \\
\hline Eumolpinae sp. 10 & 1 & 1 & 1 \\
\hline
\end{tabular}


Tab. I. Cont.

\begin{tabular}{lccc}
\hline Taxa & Sites & Freq & Abundance \\
\hline Eumolpinae sp. 11 & 2 & 2 & 19 \\
Eumolpinae sp. 12 & 1 & 1 & 1 \\
Eumolpinae sp. 13 & 3 & 4 & 4 \\
Eumolpinae sp. 14 & 1 & 1 & 1 \\
Eumolpinae sp. 15 & 1 & 1 & 1 \\
Eumolpinae sp. 16 & 1 & 1 & 1 \\
Total: 99 species & & & 450 \\
\hline
\end{tabular}
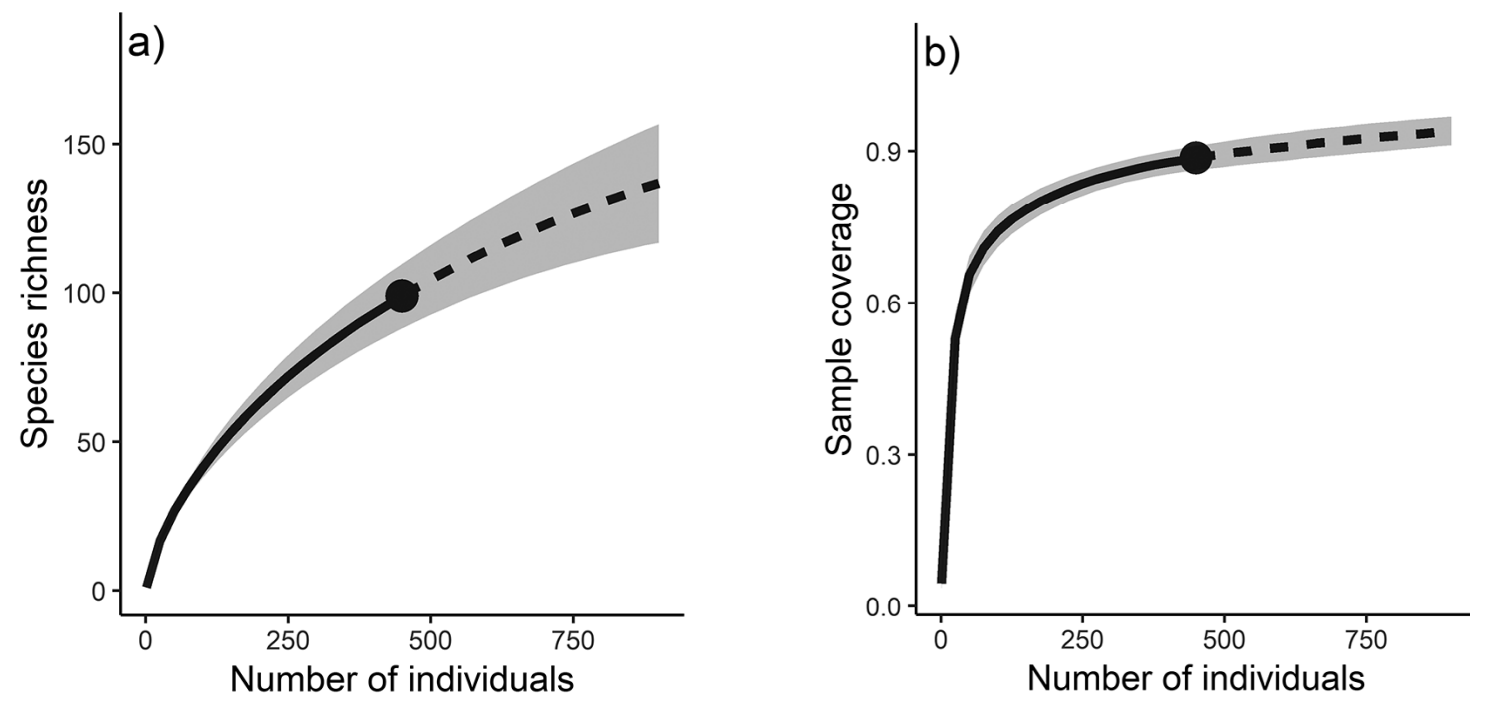

Fig. 2. Rarefaction and extrapolation curve (a) and sample-coverage curve (B) of Chrysomelidae assemblage from remnant forest fragments in Dourados, Mato Grosso do Sul, Brazil. In both figures, solid lines represent observed data, dashed lines represent the extrapolation (900 individuals) and shaded areas the $95 \%$ confidence intervals (based on a bootstrap method with 1,000 replications).

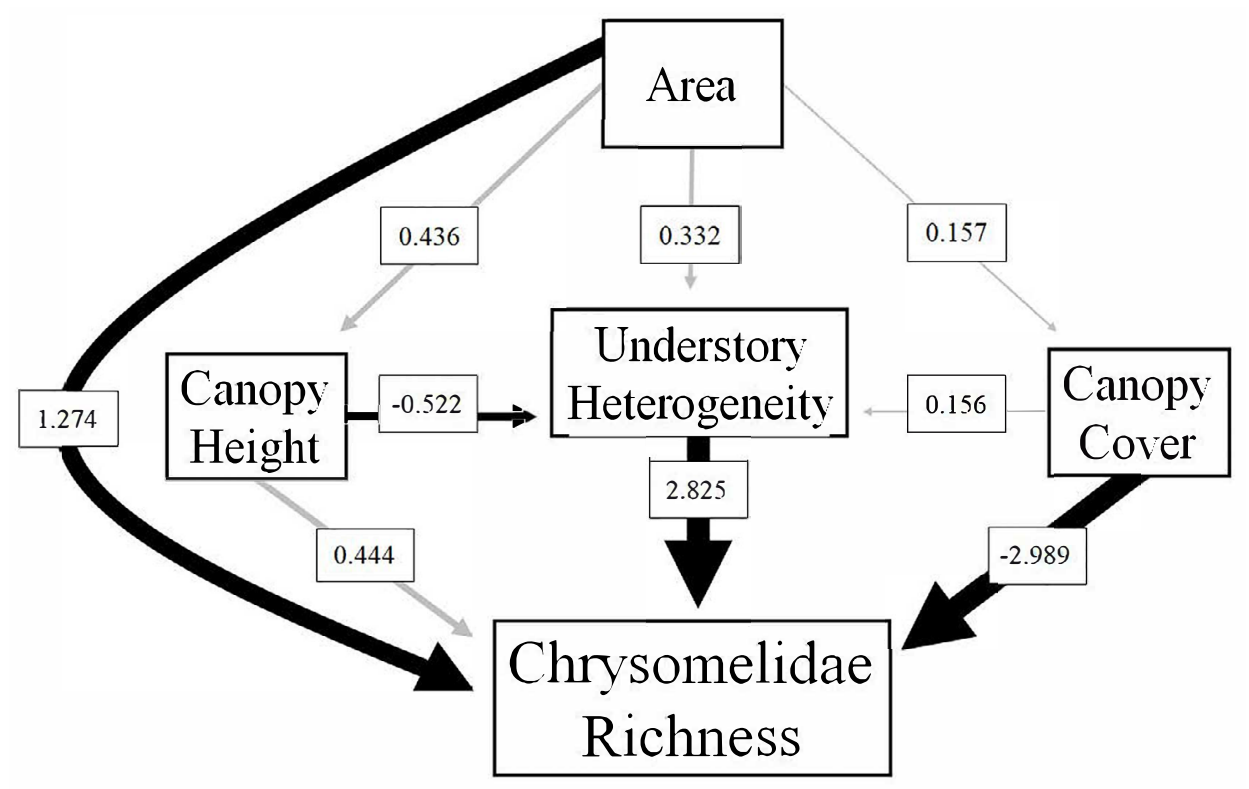

Fig. 3. Path diagram showing the direct and indirect effects of the variables on the Chrysomelidae species richness from remnant forest fragments in Dourados, Mato Grosso do Sul, Brazil. The directions of the arrows indicate the direction of effects and the width of arrows is proportional to the effect size. The black arrows indicate significant effects $($ alpha $\leq 0.05)$ and the gray arrows indicate insignificant effects.

as sample size increases (CodDington et al., 2009). In fact, this case does not interfere with our results as shown in the sample coverage. Although there are many other species that were not found in our survey, the sample coverage indicates that about $88 \%$ of the individuals in the community belong to the species captured herein.

A large number of singleton and doubleton species that constitute Chrysomelidae assemblages have frequently 
been shown in studies about communities from different locations (e.g. LinzMEIER \& Ribeiro-Costa, 2012, Pimenta \& De Marco, 2015) using different collection methods (e.g. SÁNCHEZ-REYES et al., 2014). However, although these species are common in the tropics, a large representation of insect species with low abundance may be due to collection methods (passive collection traps, as Malaise traps, can capture many transitional species), eating habits of species (polyphagia) or since they are genuinely rare species (with low population levels) (NOvOTNÝ \& BASSET, 2000). Forest environments in early/intermediate stages of ecological succession have a higher number of phytophagous beetle species when compared to environments in more advanced successional stages (MARINONI \& GANHO, 2006), which is also found for Chrysomelidae (LiNZMEIER et al., 2006).

As observed in the path analysis results, area and understory heterogeneity have positive direct effects on species richness of the Chrysomelidae assemblage, while canopy cover has a negative one. An indirect effect was observed in the canopy height; however, it was the only variable that had an indirect effect (via understory heterogeneity) on species richness. According to the classical species-area relationship, increasing the size of an area should enable more species to coexist, as a consequence of greater availability of resource and an increase in ecological niches (Tews et al., 2004). No indirect effects of area on species richness were observed, showing that the canopy structure and heterogeneity of the understory were not dependent on the size of fragments in the landscape studied. However, we cannot discard that the area can exert an indirect effect on species richness. For example, increasing the size of area leads to an increase in Chrysomelidae species richness, improving plant abundance and richness (GERSTNER et al., 2014) and allowing more species of leaf beetles to coexist.

Regarding understory heterogeneity, increasing it represents an increase in the habitat structural complexity. More heterogeneous environments tend to have more species with a greater number of niches (MACARTHUR \& MacArthur, 1961), therefore, species coexistence is promoted, as shown by OHSAWA \& NAGAIKe (2006) who found more Chrysomelidae species in places where the understory was more complex (represented by the richness of vascular plant species $<2 \mathrm{~m}$ height).

The Chrysomelidae assemblage responded negatively to canopy cover, reducing the number of species as the proportion of canopy cover increased. In tropical forests, natural openings in the canopy are essential to maintain plant diversity in the understory (SCHNITZER \& CARSON, 2001), as they interfere with the amount of light that reaches the understory, thus influencing the composition and diversity of arthropods (GRUNDEL et al., 1998; RICHARDS \& WINDSOR, 2007; GossNER, 2009). Although there is clear evidence for the direct effect of light on the Chrysomelidae assemblage, such effect can also act indirectly on the composition and density of the understory plant community. Canopy gap size and age (time when gap was created) in temperate forests, determine plant composition of the understory (KERN et al., 2013). The plant community composition in forests with larger gaps and more available light differs from that in forests with smaller gaps, indicating that these gaps can increase the spatial and structural heterogeneity of forest environments (KERN et al., 2013). These clearings favor the growth and development of several kinds of pioneer plants, such as grasses and shrubs, and thus increase the resources available to phytophagous insects, including Chrysomelidae. These insects are often found on herbaceous and shrub plants, with high specificity between these insects and their host plants (Jolivet, 1988; LINZMEIER \& RIBEIRO-CostA, 2012). Therefore, as plant diversity increases, the richness of these insects is expected to increase.

The canopy height variable did not directly affect the assemblages of leaf beetles but proved to be important by presenting an indirect effect on the richness of those beetles. As observed, the canopy height diminishes the understory heterogeneity and consequently diminishes species richness by reducing the amount of niches.

Chrysomelidae are insects that depend on area and structural attributes of the habitat, herein represented by structural heterogeneity of the understory, canopy cover and canopy height, which can independently or jointly influence species richness. In bigger forest remnants where there is a more heterogeneous understory and lower canopy coverage, there are more leaf beetle species. In these open woodlands, plant diversity is probably high, which could explain the higher richness of leaf beetles, who tend to maintain close relationships with their host plants. However, empirical evidence of such relationship between plant diversity and Chrysomelidae is rare, suggesting that further studies need to be carried out about plant composition, as well as the structural attributes of forest remnant areas.

Acknowledgements. We thank Cibele Stramare RibeiroCosta (Universidade Federal do Paraná) and the Taxon line staff (Paraná Network of Biological Collections) for permission to access the "Coleção Entomológica Pe. Jesus Santiago Moure”. Dr. Jelly Makoto Nakagaki (Universidade Estadual do Mato Grosso do Sul) for providing equipment and physical space at the Biodiversity Research Center laboratory. This study was financed in part by the Coordenação de Aperfeiçoamento de Pessoal de Nível Superior - Brasil (Capes) - Finance Code 001.

\section{REFERENCES}

Anderson, R. C.; Loucks, O. L. \& SwaIn, A. M. 1969. Herbaceous Response to Canopy Cover, Light Intensity, and Throughfall Precipitation in Coniferous Forests. Ecology 50(2):255-263.

Aslan, E. G. \& Ayvaz, Y. 2009. Diversity of Alticinae (Coleoptera, Chrysomelidae) in Kasnak Oak Forest Nature Reserve, Isparta, Turkey. Turkish Journal of Zoology 33(3):251-262.

BEALS, M. L. 2006. Understanding community structure: A data-driven multivariate approach. Oecologia 150(3):484-495.

Bouchard, P.; Smith, A. B. T.; Douglas, H.; Gimmel, M. L.; Brunke, A. J. \& KANDA, K. 2017. Biodiversity of Coleoptera. In: Foottit R. G. \& ADLER P. H. eds. Insect Biodiversity: Science and Society. 2ed. New York, John Wiley \& Sons, vol 1, p.337-417.

Casari, S. A. \& IDE, S. 2012. Coleoptera. In: Rafael, J. A.; Melo, G. A. R.; Carvalho, C. J. B. DE; Casari, S. A. \& Constantino, R. eds. Insetos do Brasil: Diversidade e Taxonomia. Ribeirão Preto, Holos, p. 453-535. 
CHAO, A. \& Jost, L. 2012. Coverage-based rarefaction and extrapolation: standardizing samples by completeness rather than size. Ecology 93(12):2533-2547.

Chávez, V. \& MaCDonald, S. E. 2010. The influence of canopy patch mosaics on understory plant community composition in boreal mixedwood forest. Forest Ecology and Management 259(6):1067-1075.

Coddington, J. A.; Agnarsson, I.; Miller, J. A.; Kunter, M. \& Hormiga, G. 2009. Undersampling bias: the null hypothesis for singleton species in tropical arthropods surveys. Animal Ecology 78:573-584.

Colwell, R. K. 2013. EstimateS: Statistical estimation of species richness and shared species from samples. Version 9.1. Software and User's Guide.

Flowers, R. W. \& Hanson, P. E. 2003. Leaf beetle (Coleoptera: Chrysomelidae) diversity in eight Costa Rican habitats. In: FURTH, D. G. ed. Special topics in leaf beetle biology. Moscow, Pensoft, p. 20-51.

Gerstner, K.; Dorman, C. F.; VÁclavíck, T.; Kreft, H. \& Sepelt, R. 2014. Accounting for geographical variation in species-area relationships improves the prediction of plant species richness at the global scale. Journal of Biogeography 41: 261-273.

Gossner, M. M. 2009. Light intensity affects spatial distribution of Heteroptera in deciduous forests. European Journal of Entomology 106(2):241-252.

Gotelli, N. J. \& Colwell, R. K. 2011. Estimating species richness. In: MagurRan, A. E. \& McGiLl, B. J. eds. Biological diversity: frontiers in measurement and assessment. Oxford, Oxford University Press, p. 39-54.

Greatorex-Davies, J. N.; Sparks, T. H. \& Hall, M. L. 1994. The response of heteroptera and coleoptera species to shade and aspect in rides of coniferised lowland woods in Southern England. Biological Conservation 67(3):255-273.

Grundel, R.; Pavlovic, N. B. \& Sulzman, C. L. 1998. Habitat use by the endangered Karner blue butterfly in oak woodlands: The influence of canopy cover. Biological Conservation 85(1-2):47-53.

Hshie, T. C.; MA, K. H. \& CHaO, A. 2019. iNEXT: iNterpolation and EXTrapolation for species diversity. R package v. 2.0.19. Available at $<$ http://chao.stat.nthu.ed.tw/blog/softwear-download/>. Accessed on 10 June 2019.

Jolivet, P. 1988. Food Habits and Food Selection of Chrysomelidae. Bionomic and Evolutionary Perspectives. In: P. Jolivet, E. PetitPierre, \& T. H. Hsiao eds. Biology of Chrysomelidae. Dordrecht, Kluwer Academic Publishers, p. 1-24.

JoLIVET, P. 2015. Together with 30 years of Symposia on Chrysomelidae! Memories and personal reflections on what we know more about leaf beetles. Zookeys 547:35-61.

Kern, C. C.; Motgomery, R. A.; Reich, P. B. \& Strong, T. F. 2013. Canopy gap size influences niche partitioning of the ground-layer plant community in a northern temperate forest. Journal of Plant Ecology 6(1):101-112.

LAURANCE, W. 1991. Predicting the impacts of edge effects in fragmented habitats. Biological Conservation 55:77-92.

LEGENDRE, P. \& LeGENDRE, L. 2012. Numerical Ecology. 3ed. Amsterdam, Elsevier. 1006p.

Linzmeier, A. M. \& Ribeiro-Costa, C. S. 2012. Spatial-temporal composition of Chrysomelidae (Insecta: Coleoptera) communities in southern Brazil. Journal of Natural History 46(31-32):1921-1938.

Linzmeier, A. M. \& Ribeiro-Costa, C. S. 2013.Seasonal pattern of Chrysomelidae (Coleoptera) in the state of Paraná, southern Brazil. Biota Neotropica 13(1):153-162.

Linzmeier, A. M.; Ribeiro-Costa, C. S. \& Marinoni, R. C. 2006. Fauna de Alticini (Newman) (Coleoptera, Chrysomelidae, Galerucinae) em diferentes estágios sucessionais na Floresta com Araucária do Paraná, Brasil: diversidade e estimativa de riqueza de espécies. Revista Brasileira de Entomologia 50(1):101-109.
MacArthur, R. H. \& MacArthur, J. W. 1961. On Bird Species Diversity. Ecology 42(3):594-598.

MacArthur, R. M. \& Wilson, E. O. 1963. An equilibrium theory of insular zoogeography. Evolution 17(4):373-387.

Marinoni, R. C. \& Ganho, N. G. 2006. A diversidade diferencial beta de Coleoptera (Insecta) em uma paisagem antropizada do Bioma Araucária. Revista Brasileira de Entomologia 50(1):64-71.

Novotný, V. \& BASSET, Y. 2000. Rare species in communities of tropical insect herbivores: pondering the mystery of singletons. Oikos 89:564572.

OHSAWA, M. \& NAGAiKe, T. 2006. Influence of forest types and effects of forestry activities on species richness and composition of Chrysomelidae in the central mountainous region of Japan. Biodiversity and Conservation 15:1179-1191.

Ohsawa, M. \& Shimokawa, T. 2011. Extending the rotation period in larch plantations increases canopy heterogeneity and promotes species richness and abundance of native beetles: Implications for the conservation of biodiversity. Biological Conservation 144(12):31063116.

Pimenta, M. \& De Marco, P. JR. 2015. Leaf beetle (Chrysomelidae: Coleoptera) assemblages in a mosaic of natural and altered areas in the Brazilian Cerrado. Neotropical Entomology 44:242-255.

Prescott, C. E. 2002. The influence of the forest canopy on nutrient cycling. Tree Physiology 22(15-16):1193-1200.

R Core Team. 2019. R: a language and environment for statistical computing. Available at $<$ https://www.R-project.org/>. Accessed on 10 June 2019.

RICHARDS, L. A. \& WINDSOR, D. M. 2007. Seasonal variation of arthropod abundance in gaps and the understorey of a lowland moist forest in Panama. Journal of Tropical Ecology 23(2):169-176.

Riley, E. G.; Clark, S. M.; Flowers, R. W. \& Gilbert, A. J. 2002. Chrysomelidae Latreille 1802. In: Arnet JR, R. H.; Thomas, M. C.; Skelley, P. E. \& Frank, J. H. eds. American Beetles. Polyphaga: Scarabaeoidea through Curculionoidea. (pp. 617-691). United States of America, CRC Press LLC. v.2, p.617-691.

RosenZweig, M. L. 1995. Species diversity in space and time. Cambridge, Cambridge University Press. 458p.

Rosseel, Y. 2012. lavaan: an R package for structural equation modeling. Journal of Statistical Software 48(2):1-36

SÁnchez-Reyes, U. J.; Niño-Maldonado, S. \& Jones, R. W. 2014. Diversity and altitudinal distribution of Chrysomelidae (Coleoptera) in Peregrina Canyon, Tamaulipas, Mexico. ZooKeys 417:103-132.

Scheiner, S.; Mitchell, R. \& Callahan, H. 2000. Using path analysis to measure natural selection. Journal of Evolutionary Biology 13(3):423-433.

SCHNITZER, S. A. \& CARSON, W. P. 2001. Treefall gaps and the maintenance of species diversity in a tropical forest. Ecology 82(4):913-919.

Schowalter, T. D. 2006. Insect Ecology: An Ecosystem Approach. 2ed. London, Elsevier Academic Press. 576p.

Shaw, D. C. \& Bible, K. 1996. An overview of forest canopy ecosystem functions with reference to urban and riparian systems. Northwest Science 70(Special Issue):1-6.

Silva, R. J. DA; Diniz, S. \& VAZ-DE-Mello, F. Z. 2010. Heterogeneidade do habitat, riqueza e estrutura da assembléia de besouros rola-bostas (Scarabaeidae: Scarabaeinae) em áreas de cerrado na Chapada dos Parecis, MT. Neotropical Entomology 39(6):934-940.

Smith, R. W. \& WhittakeR, J. B. 1980. The influence of habitat type on the population dynamics of Gastrophysa viridula Degeer (Coleoptera: Chrysomelidae). Journal of Animal Ecology 49(1):225-236.

Tews, J.; Brose, U.; Grimm, V.; Tielbörger, K.; Wichmann, M. C.; Schwager, M. \& Jeltsch, F. 2004. Animal species diversity driven by habitat heterogeneity/ diversity: the importance of keystone structures. Journal of Biogeography 31:79-92. 